\title{
Zincalstibite-9R: the first nine-layer polytype with the layered double hydroxide structure-type
}

S. J. Mills ${ }^{1, *}$, A. G. Christy ${ }^{2}$, A. R. KampF $^{3}$, R. M. Housley $^{4}$, G. Favreau ${ }^{5}$, J.-C. Boulliard ${ }^{6}$ and

V. BOURGOIN ${ }^{6}$

1 Geosciences, Museum Victoria, GPO Box 666, Melbourne, Victoria 3001, Australia

2 Centre for Advanced Microscopy, Sullivans Creek Road, Australian National University, Canberra 0200, Australia

3 Mineral Sciences Department, Natural History Museum of Los Angeles County, 900 Exposition Boulevard, Los Angeles, California 90007, USA

4 Division of Geological and Planetary Sciences, California Institute of Technology, Pasadena, California 91125, USA

5421 Avenue Jean Monnet, 13090 Aix-en-Provence, France

6 Association Jean Wyart, Collection des Minéraux de Jussieu, IMPMC, Université Pierre et Marie Curie, case courrier 73, 4, place Jussieu, F-75252 Paris Cedex 05, France

[Received 22 April 2012; Accepted 3 June 2012; Associate Editor: Elena Sokolova]

\section{ABSTRACT}

Zincalstibite- $9 R$, a new polytype in the hydrotalcite supergroup is reported from the Monte Avanza mine, Italy. It occurs as pale blue curved disc-like tablets flattened on $\{001\}$ intergrown to form rosettes typically less than $50 \mu \mathrm{m}$ in diameter, with cyanophyllite and linarite in cavities in baryte. Zincalstibite- $9 R$ is uniaxial (-), with refractive indices $\omega=1.647(2)$ and $\varepsilon=1.626(2)$ measured in white light. The empirical formula (based on $12 \mathrm{OH}$ groups) is $\left(\mathrm{Zn}_{1.09}^{2+} \mathrm{Cu}_{0.87}^{2+} \mathrm{Al}_{0.04}\right)_{\Sigma 2.00} \mathrm{Al}_{1.01}$ $\left(\mathrm{Sb}_{0.97}^{5+} \mathrm{Si}_{0.02}\right)_{\Sigma 0.99}(\mathrm{OH})_{12}$, and the ideal formula is $(\mathrm{Zn}, \mathrm{Cu})_{2} \mathrm{Al}(\mathrm{OH})_{6}\left[\mathrm{Sb}(\mathrm{OH})_{6}\right]$. Zincalstibite- $9 R$ crystallizes in space group $R \overline{3}$, with $a=5.340(2), c=88.01(2) \AA, V=2173.70(15) \AA^{3}$ and $Z=9$. The crystal structure was refined to $R_{1}=0.0931$ for 370 unique reflections $\left[F_{\mathrm{o}}>4 \sigma(F)\right]$ and $R_{1}=$ 0.0944 for all 381 unique reflections. It has the longest periodic layer stacking sequence for a layered double hydroxide compound reported to date.

KEYwORDs: zincalstibite, cualstibite, hydrotalcite, layered double hydroxide, LDH, polytype, crystal structure, Monte Avanza.

\section{Introduction}

LAYERED DOUBLE HYDROXIDES (LDHs) are a large group of compounds that contain brucite-like layers of stoichiometry $M X_{2}$, where $M$ represents one or more cations octahedrally coordinated by $X$ anions, which are dominantly or entirely $\mathrm{OH}^{-}$. The brucite-like layers have a net positive charge, which is balanced by intercalated negatively

*E-mail: smills@museum.vic.gov.au

DOI: $10.1180 /$ minmag.2012.076.5.01 charged ions. Neutral molecules such as $\mathrm{H}_{2} \mathrm{O}$ are also present in the interlayer spaces in many cases. The interlayer anions are usually common groups such as $\mathrm{CO}_{3}^{2-}, \mathrm{SO}_{4}^{2-}$ and $\mathrm{Cl}^{-}$, but they include less well known groups such as $\left[\mathrm{Sb}(\mathrm{OH})_{6}\right]^{-}$.

There are more than 40 known LDH mineral species. These are classified mineralogically in the hydrotalcite supergroup, and are comprehensively reviewed in a current report by the Commission for New Minerals, Nomenclature and Classification of the International Mineralogical Association (Mills et al., 2012b). Here, we report a new polytype of zincalstibite, a 


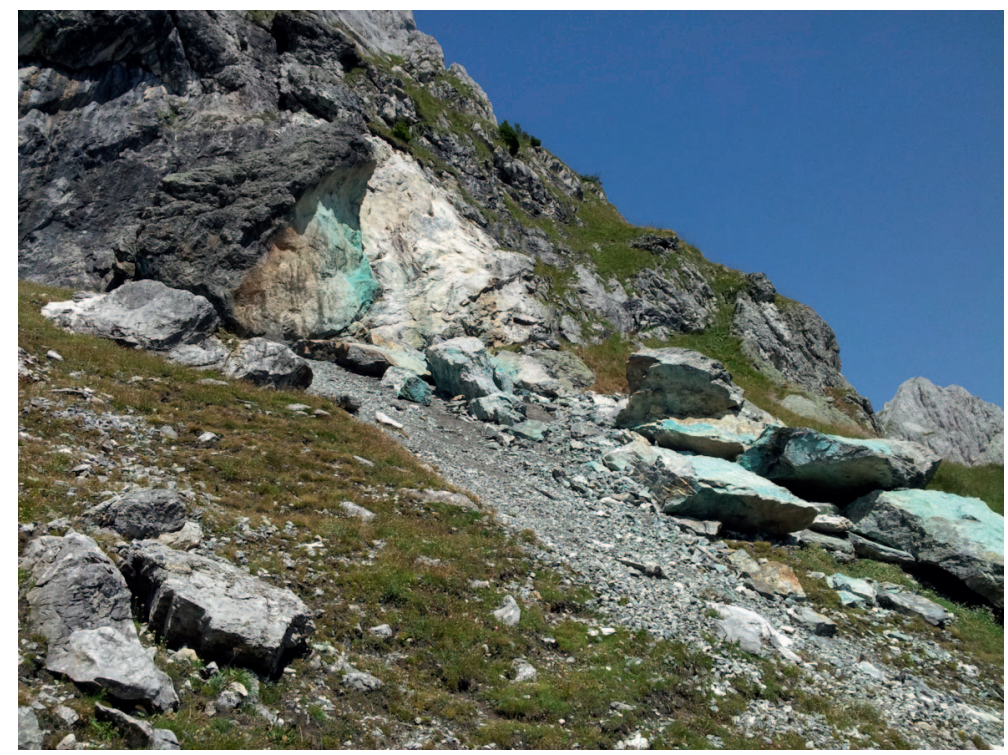

FIG. 1. Malachite-stained boulders at 'Pietra Verde' on Monte Avanza.

hydrotalcite-supergroup mineral that is of particular structural significance as it has the longest periodic layer stacking sequence for an $\mathrm{LDH}$ compound reported to date.

\section{Occurrence and paragenesis}

The Monte Avanza Cu-Ag mine is located on the southern side of Monte Avanza (2484 m) near the town of Pierabec in the municipality of Forni Avoltri, Udine Province, Friuli-Venezia Giulia, Italy. It has been worked for $\mathrm{Cu}$ and $\mathrm{Ag}$ sporadically since ancient times (first reference dated 778 AD). Between 1639 and 1925, about ten levels were cut into a quartz porphyry and black shale complex of Carboniferous age to reach the orebody which is located at the contact with Devonian limestone. The most productive period of mining was between 1857 and 1876; returns from later small-scale mining were insignificant.

Supergene alteration of primary tetrahedritetennantite, galena, sphalerite and pyrite has produced an interesting assemblage of secondary $\mathrm{Cu}-, \mathrm{Zn}-, \mathrm{Fe}-$ and Sb-bearing minerals including chalcophyllite, cyanophyllite, cualstibite, camer-
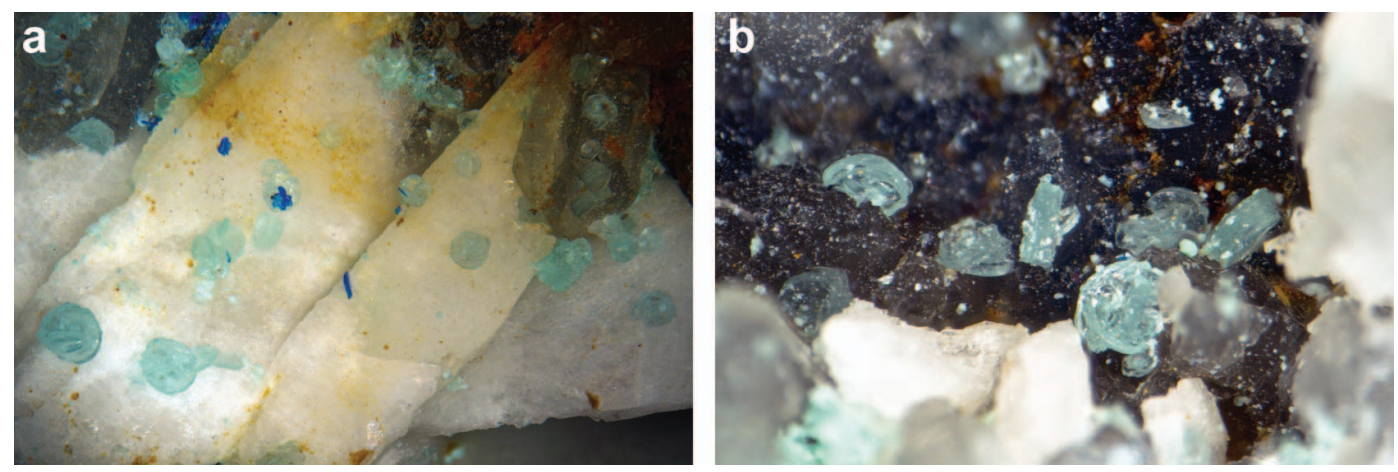

FIG. 2. (a) Clusters of zincalstibite-9R (pale blue) with linarite (dark blue) on baryte and quartz. The field of view is $\sim 1.8 \mathrm{~mm}$. (b) Clusters of zincalstibite- $9 R$ on goethite and quartz. The field of view is $\sim 1.2 \mathrm{~mm}$. 
TABle 1. Analytical data for zincalstibite-9R.

\begin{tabular}{lcccc}
\hline Constituent & Mean (wt.\%) & Range & SD & Standard \\
\hline $\mathrm{CuO}$ & 14.56 & $13.40-15.35$ & 1.02 & cuprite \\
$\mathrm{ZnO}$ & 18.61 & $17.64-19.75$ & 1.07 & zincite \\
$\mathrm{Al}_{2} \mathrm{O}_{3}$ & 11.27 & $11.08-11.43$ & 0.18 & anorthite \\
$\mathrm{Sb}_{2} \mathrm{O}_{5}$ & 33.19 & $33.02-33.39$ & 0.18 & Sb metal \\
$\mathrm{SiO}_{2}$ & 0.24 & $0.15-0.30$ & 0.08 & anorthite \\
$\mathrm{H}_{2} \mathrm{O}_{\text {calc }}$ & 22.77 & & & \\
Total & 100.64 & & & \\
\hline
\end{tabular}

olaite and theisite (Ciriotti et al., 2006). This assemblage shares some features with those at the Clara mine, Germany (Wendel and Bayerl, 2001) and the Tistoulet mine near Padern, Aude, France (Favreau et al., 2003).

The specimen of zincalstibite-9R was collected at a site known as 'Pietra Verde' (literally 'Green Stone'). At this locality, large malachite-stained blocks derived from nearby veins have fallen to the base of a limestone cliff (Fig. 1). Zincalstibite- $9 R$ occurs with cyanophyllite and linarite in cavities in baryte, which may also be lined with quartz and goethite. The studied specimen is preserved in the collections of the Natural History Museum of Los Angeles County, under catalogue number 63840 .

\section{Physical and optical properties}

Zincalstibite- $9 R$ most commonly occurs as pale blue curved disc-like tablets, flattened on $\{001\}$ and bounded by indistinct forms in the [001] zone, similar to the habit exhibited by the new mineral omsite (IMA2012-025; Mills et al., 2012a). The tablets are commonly intergrown to form rosettes (Fig. 2), which are typically about $20 \mu \mathrm{m}$ in diameter, and rarely exceed $50 \mu \mathrm{m}$ in diameter. Individual crystallites are no more than $\sim 10 \mu \mathrm{m}$ thick.

Optically, zincalstibite- $9 R$ is uniaxial $(-)$, with refractive indices $\omega=1.647(2)$ and $\varepsilon=1.626(2)$ measured in white light. These refractive indices are lower than those reported for cualstibite, $\omega=$ 1.672(2) and $\varepsilon=1.644(2)$, which contains no $\mathrm{Zn}$ (Walenta, 1984). Bonaccorsi et al. (2007) were unable to measure the refractive indices of type zincalstibite. Assuming that they decrease linearly as the $\mathrm{Zn}$ content increases, extrapolation using data for the $\mathrm{Zn}$-free mineral and our compositionally intermediate material, suggests that the refractive indices of endmember zincalstibite are approximately $\omega=1.627$ and $\varepsilon=1.612$.

TABLe 2. Powder X-ray data for zincalstibite-9R.

\begin{tabular}{|c|c|c|c|c|}
\hline$I_{\mathrm{obs}}$ & $d_{\text {obs }}$ & $d_{\text {calc }} *$ & $I_{\text {calc }}{ }^{*}$ & $h k l$ \\
\hline 23 & 9.811 & 9.758 & 27 & $\begin{array}{lll}0 & 0 & 9\end{array}$ \\
\hline 100 & 4.886 & 4.879 & 100 & 0.0 .18 \\
\hline 28 & 4.550 & 4.572 & 18 & 102 \\
\hline 6 & 4.225 & 4.240 & 1 & 108 \\
\hline 9 & 3.758 & 3.708 & 6 & 1.0 .14 \\
\hline 27 & 2.6625 & 2.6542 & 24 & 110 \\
\hline 11 & 2.5674 & 2.5611 & 7 & $11 \underline{9}$ \\
\hline \multirow{2}{*}{73} & $23382\}$ & 2.3315 & 17 & 1.1 .18 \\
\hline & 2.3382 & 2.3315 & 38 & 1.1 .18 \\
\hline 5 & 2.1541 & 2.1582 & 1 & 0.2 .14 \\
\hline \multirow[t]{2}{*}{5} & 2.0611 & 2.0564 & 6 & 1.1 .27 \\
\hline & & 1.9693 & $<1$ & 0.2 .23 \\
\hline \multirow[t]{2}{*}{6} & 1.9714 & 1.9663 & $<1$ & 1.1 .30 \\
\hline & & 1.9663 & $<1$ & 1.1 .30 \\
\hline \multirow{4}{*}{43} & $17983\}$ & 1.7961 & 14 & 1.1 .36 \\
\hline & 1.19007 & 1.7961 & 19 & 1.1 .36 \\
\hline & & 1.7372 & $<1$ & 121 \\
\hline & & 1.7372 & $<1$ & 211 \\
\hline \multirow{5}{*}{13} & 17365 & 1.7362 & $<1$ & 212 \\
\hline & 1.1703 & 1.7362 & $<1$ & $12-2$ \\
\hline & & 1.7321 & $<1$ & 124 \\
\hline & & 1.7321 & $<1$ & $21 \overline{4}$ \\
\hline & & 1.6469 & $<1$ & 2.1 .17 \\
\hline 5 & $1.64\}$ & 1.6469 & $<1$ & 1.2 .17 \\
\hline 18 & 1.5388 & 1.5324 & 8 & $\begin{array}{lll}3 & 0 & 0\end{array}$ \\
\hline \multirow{2}{*}{17} & $14656\}$ & 1.462 & 5 & 3.0 .18 \\
\hline & 1.4050 & 1.462 & 5 & 0.3 .18 \\
\hline \multirow{2}{*}{14} & & 1.3867 & 4 & 1.1 .54 \\
\hline & 1.5800 & 1.3867 & 5 & 1.1 .54 \\
\hline 8 & 1.3316 & 1.3271 & 3 & 220 \\
\hline
\end{tabular}

* The $d_{\text {calc }}$ and $I_{\text {calc }}$ values are from single crystal data. 


\section{Chemical composition}

Quantitative chemical analyses (3) of zincalstibite- $9 R$ were carried out on a JEOL8200 electron microprobe operating in wavelength-dispersive spectrometry (WDS) mode at a $15 \mathrm{kV}$ accelerating voltage, $5 \mathrm{nA}$ beam current and $5 \mu \mathrm{m}$ beam diameter (Division of Geological and Planetary Sciences, California Institute of Technology). The quantitative elemental microanalyses were processed with the CITZAF correction procedure. No elements other than $\mathrm{Al}$, $\mathrm{Si}, \mathrm{Cu}, \mathrm{Zn}$ and $\mathrm{Sb}$ were detected in a separate examination by energy-dispersive spectrometry (Pierre et Marie Curie University, Paris). Water could not be measured directly due to the small amount of material available, but it was identified in the crystal-structure analysis. The amount of $\mathrm{H}_{2} \mathrm{O}$ was calculated assuming that all anions are hydroxide. Analytical data and standards are listed in Table 1.

The empirical formula, normalized on $6 \mathrm{O}$ p.f.u. in the anhydrous equivalent, and consistent with $12(\mathrm{OH})$ p.f.u. as found in cualstibite and zincalstibite, is: $\left(\mathrm{Zn}_{1.09}^{2+} \mathrm{Cu}_{0.87}^{2+} \mathrm{Al}_{0.04}\right)_{\Sigma 2.00} \mathrm{Al}_{1.01}$ $\left(\mathrm{Sb}_{0.97}^{5+} \mathrm{Si}_{0.02}\right)_{\Sigma 0.99}(\mathrm{OH})_{12}$. The corresponding ideal formula is $(\mathrm{Zn}, \mathrm{Cu})_{2} \mathrm{Al}(\mathrm{OH})_{6}\left[\mathrm{Sb}(\mathrm{OH})_{6}\right]$.

\section{Powder X-ray diffraction}

Powder X-ray diffraction data for zincalstibite- $9 R$ were obtained on a Rigaku R-Axis Rapid II curved imaging plate microdiffractometer using monochromatic $\mathrm{Mo} K \alpha$ radiation. The observed $d$ spacings and intensities were derived by profile fitting using JADE 9.1 software, and these data are listed in Table 2. The unit-cell parameters refined from the powder data using JADE 9.1 with whole pattern fitting are $a=5.3086(16)$ and $c=$ 87.83(3) $\AA$. The observed powder data are in good agreement with those calculated from the structure (Table 2).

\section{Single-crystal X-ray diffraction}

Single-crystal data were collected on the instrument noted above (Table 3). The Rigaku CrystalClear software package was used to process the diffraction data, including the application of an empirical absorption correction. The crystal structure of zincalstibite- $9 R$ was solved in space group $R \overline{3}$ using SHELXL-97 (Sheldrick, 2008). The Patterson method (Patterson, 1934) was used to determine the positions of heavy atoms in the unit cell, and

TABLE 3. Data collection and structure refinement details for zincalstibite- $9 R$.

Simplified formula
Temperature
X-ray wavelength
Space group
Unit-cell dimensions
Volume
$Z$

Absorption coefficient

$F(000)$

Theta range for data collection

Index ranges

Reflections / unique

Refinement method

Data / restraints / parameters

Goodness-of-fit on $F^{2}$

Final $R$ indices $[I>4 \sigma(I)]$

$R$ indices (all data)

Extinction coefficient

Largest diff. peak and hole

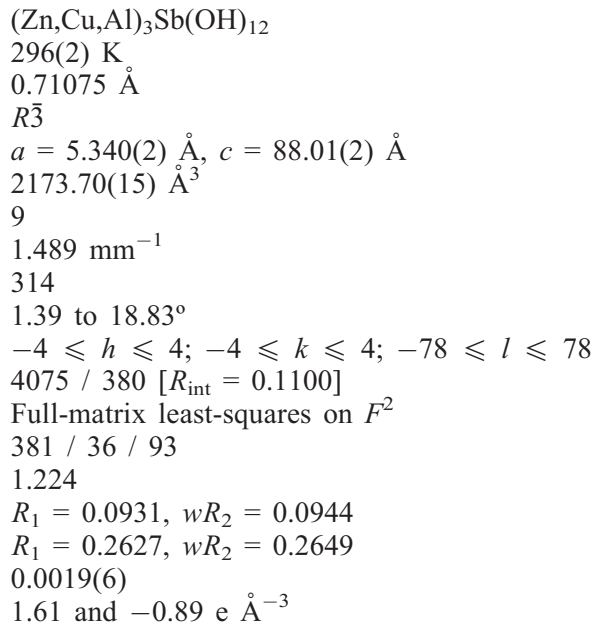




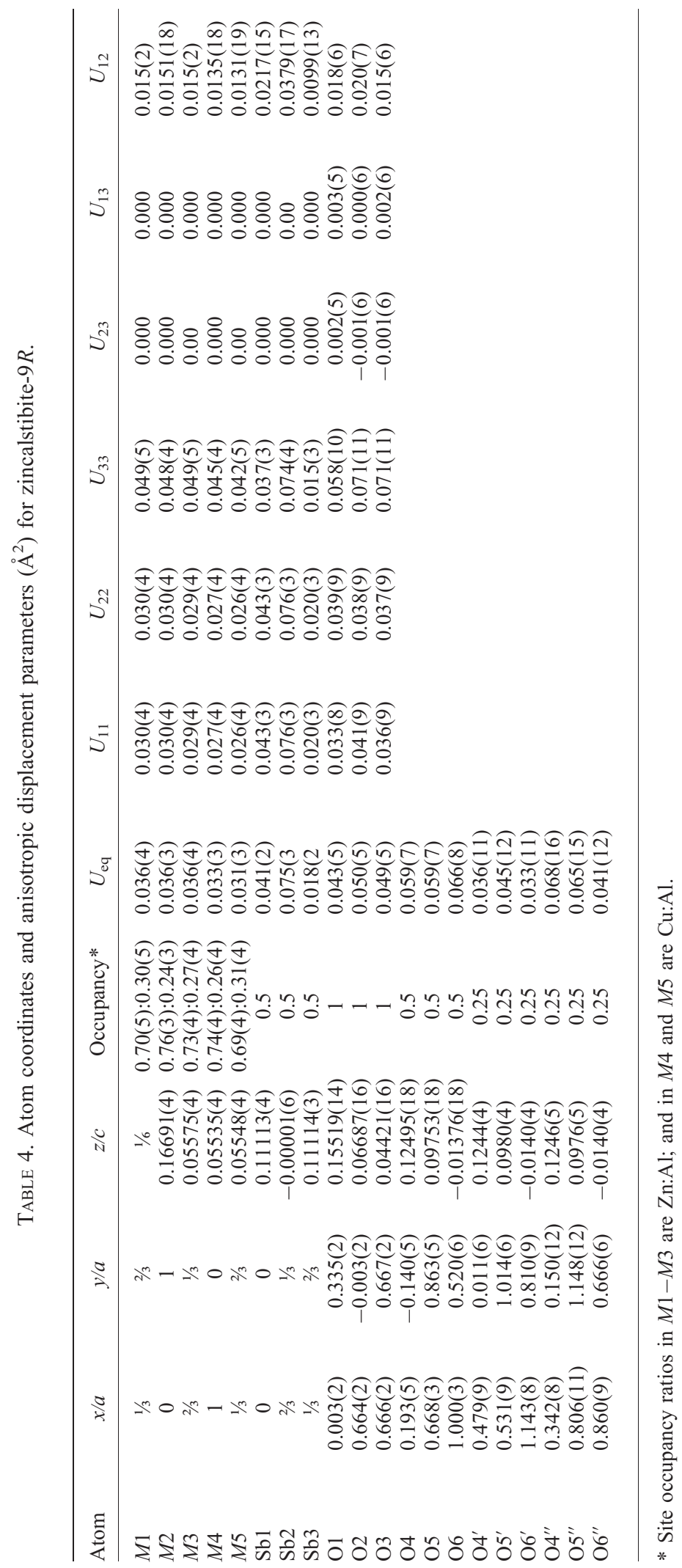


TABLE 5. Selected bond distances $(\AA)$ in zincalstibite- $9 R$.

\begin{tabular}{|c|c|c|c|c|}
\hline$M 1-\mathrm{O} 1$ & $2.037(12) \times 6$ & $\begin{array}{l}\mathrm{Sb} 1-\mathrm{O} 5 \\
\mathrm{Sb} 1-\mathrm{O} 4\end{array}$ & $\begin{array}{l}1.953(15) \\
1.968(15)\end{array}$ & $\begin{array}{l}\times 3 \\
\times 3\end{array}$ \\
\hline$M 2-\mathrm{O} 1$ & $2.047(11) \times 3$ & $\mathrm{Sb} 1-\mathrm{O} 4^{\prime \prime}$ & $1.983(18)$ & $\times 3$ \\
\hline$M 2-\mathrm{O} 1$ & $2.057(11) \times 3$ & $\mathrm{Sb} 1-\mathrm{O} 5^{\prime \prime}$ & $1.983(18)$ & $\times 3$ \\
\hline$<M 2-\mathrm{O}>$ & 2.052 & $\begin{array}{l}<\text { Sb1 }- \text { O }> \\
<\text { Sb1 }-\mathbf{O}^{\prime}>\end{array}$ & $\begin{array}{l}1.961 \\
1.983\end{array}$ & \\
\hline$M 3-\mathrm{O} 2$ & $2.038(12) \times 3$ & & & \\
\hline M3-O3 & $2.052(12) \times 3$ & $\mathrm{Sb} 2-\mathrm{O} 6$ & $1.962(15)$ & $\times 3$ \\
\hline$<M 3-O>$ & 2.045 & $\begin{array}{l}\mathrm{Sb} 2-\mathrm{O}^{\prime} \\
\mathrm{Sb} 2-6^{\prime \prime}\end{array}$ & $\begin{array}{l}1.977(17) \\
1.97(17)\end{array}$ & $\begin{array}{l}\times 3 \\
\times 3\end{array}$ \\
\hline$M 4-\mathrm{O} 3$ & $2.038(12) \times 3$ & $<\mathbf{S b 2}-\mathbf{O}>$ & 1.964 & \\
\hline $\begin{array}{l}M 4-\mathrm{O} 2 \\
<M 4-0>\end{array}$ & $\begin{array}{l}2.052(12) \times 3 \\
2.045\end{array}$ & $<\mathbf{S b 2}-\mathbf{O}^{\prime}>$ & 1.976 & \\
\hline & & $\mathrm{Sb} 3-\mathrm{O} 4$ & $1.969(15)$ & $\times 3$ \\
\hline$M 5-\mathrm{O} 2$ & $2.029(11) \times 3$ & $\mathrm{Sb} 3-\mathrm{O} 5$ & $1.964(15)$ & $\times 3$ \\
\hline M5-O3 & $2.036(11) \times 3$ & $\mathrm{Sb} 3-\mathrm{O} 4^{\prime}$ & $1.983(17)$ & $\times 3$ \\
\hline$<M 5-\mathrm{O}>$ & 2.033 & $\begin{array}{l}\mathrm{Sb} 3-\mathrm{O}^{\prime} \\
<\text { Sb3 }-\mathbf{O}^{>}> \\
<\text {Sb3 }-\mathbf{O}^{\prime}>\end{array}$ & $\begin{array}{l}1.983(17) \\
\mathbf{1 . 9 6 7} \\
\mathbf{1 . 9 8 3}\end{array}$ & $\times 3$ \\
\hline
\end{tabular}

the $\mathrm{O}$ atoms were located in subsequent difference-Fourier syntheses. In the later stages of the refinement, it became apparent that the $\mathrm{O}$ atom sites in the $\left[\mathrm{Sb}(\mathrm{OH})_{6}\right]$ layers were multiply split. In these cases (O4-O6) two extra sites located near the $\mathrm{O}$ atoms were added and designated $\mathrm{O}^{\prime}$ and $\mathrm{O}^{\prime \prime}, \mathrm{O}^{\prime}$ and $\mathrm{O}^{\prime \prime}$ and $\mathrm{O}^{\prime}$ and O6" $^{\prime \prime}$. If they were allowed to freely refine, the occupancies of the split sites and the isotropic temperature factors were unstable. The main site was therefore constrained to $50 \%$ occupancy and the other two sites to $25 \%$ occupancy each. This approach produced a stable refinement with acceptable displacement parameters. As these sites were split, the $\mathrm{Sb}-\mathrm{O}$ bond lengths were softly constrained to $1.98(3) \AA$, which is consistent with pentavalent $\mathrm{Sb}$ in octahedral coordination (Mills et al., 2009).

The refinement of the metal site-occupancies was undertaken by assigning $\mathrm{Zn}+\mathrm{Al}$ to the $M 1-M 3$ sites and $\mathrm{Cu}+\mathrm{Al}$ to the $M 4$ and $M 5$ sites in order to approximate the chemical analysis. The total refined occupancy of these sites was $\mathrm{Zn}_{1.23} \mathrm{Cu}_{0.96} \mathrm{Al}_{0.81}$, which is slightly lower in $\mathrm{Al}$ and higher in $\mathrm{Zn}$ than the analyses by WDS; however, it is still consistent with zincalstibite. Due to the similar scattering powers of $\mathrm{Cu}$ and $\mathrm{Zn}$, it is impossible to accurately refine them in conjunction with $\mathrm{Al}$, given that $\mathrm{Al}$ is present in almost the same proportion at every site. Therefore, there is no evidence for long-range order of $\mathrm{Cu}$ and $\mathrm{Zn}$ within the $9 R$ unit cell, although short-range order would be suspected on crystal-chemical grounds given that $\mathrm{Cu}^{2+}$, unlike $\mathrm{Zn}^{2+}$, prefers a Jahn-Teller-distorted coordination environment.

The final model, with all sites except the multiply split oxygens refined anisotropically, converged to $R_{1}=0.0931$ for 370 unique reflections $\left[F_{\mathrm{o}}>4 \sigma(F)\right]$ and $R_{1}=0.0944$ for all 381 unique reflections. Details of the data collection and structure refinement are provided in Table 3. Final fractional coordinates, atom displacement parameters and occupancies are listed in Table 4. Selected interatomic distances are given in Table 5. The bond-valence analysis in Table 6 shows that calculated values are exceptionally close to the theoretical values. A crystallographic information file has been deposited with Mineralogical Magazine and is available at http://www.minersoc.org/pages/e journals/ dep_mat_mm.html.

Zincalstibite-9R is a LDH mineral, isostructural with members of the hydrotalcite supergroup and cualstibite group (Mills et al., 2012b). The structure consists of a $(\mathrm{Zn}, \mathrm{Cu})_{2} \mathrm{Al}(\mathrm{OH})_{6}$ brucitelike layer, with $\mathrm{Sb}(\mathrm{OH})_{6}$ octahedra in the interlayer (Fig. 3). The topology is consistent with that described by Bonaccorsi et al. (2007) for cualstibite and zincalstibite. Bonaccorsi et al. (2007) solved the structure of zincalstibite in space group $P \overline{3}$, with $a=5.321(1), c=9.786(2) \AA$ 
and $Z=1$, consistent with the $1 T$ polytype with a $\sqrt{ } 3 \times \sqrt{ } 3$ superstructure in the $x y$ plane. The structure of cualstibite was solved in space group $P \overline{3}$, with $a=9.150(2), c=9.745(2) \AA$ and $Z=3$, which is the $1 T$ polytype with a $3 \times 3$ superstructure in the $x y$ plane. The zincalstibite polytype described here in space group $R \overline{3}$, has $a=5.340(2), c=88.01(2) \AA$ and $Z=9$, and has the same $\sqrt{3} \times \sqrt{3}$ superstructure in the $x y$ plane as zincalstibite-1T; however, the repeat perpendicular to the layers is $9 \times$ rather than the $1 \times$ in both of the other structures.

An interesting feature of zincalstibite- $9 R$ that contrasts with cualstibite- $1 T$ and zincalstibite- $1 T$ is that all of the metal sites have essentially the same mean bond distance of $2.045 \pm 0.01 \AA$ (Table 5). In the structure of cualstibite-1T, $\mathrm{Cu}$ and $\mathrm{Al}$ are completely ordered on distinct sites, allowing formation of a typical Jahn-Tellerdistorted $\mathrm{Cu}^{2+}$ environment (Bonaccorsi et al., 2007). In the zincalstibite- $1 T$ structure there is a small amount of disorder in the metal siteoccupancies which are $\mathrm{Zn}_{0.81} \mathrm{Al}_{0.19}$ and $\mathrm{Al}_{0.63} \mathrm{Zn}_{0.37}$, respectively (Bonaccorsi et al., 2007). The $9 R$ structure is a superstructure of the $1 T$ structure produced by two types of octahedral layers, one of which $(A)$ has symmetrically distinct cation sites $M 1$ and $M 2$, and the other $(B)$ has $M 3-M 5$. Regular interlayering of these two types of cation occurs in layers in an ...ABBABBABB... stacking sequence with lateral offsets of the site ordering patterns within each $A$ or $B$ layer that are consistent with the $R$ lattice. Relaxations in the orientations of $\mathrm{OH}$ and $\left[\mathrm{Sb}(\mathrm{OH})_{6}\right]$ groups would be expected to couple strongly to cation ordering within the layers, and may be evidenced by the site splitting of oxygens bonded to $\mathrm{Sb}$. However, such displacements would be relatively minor contributors to the $\mathrm{X}$ ray scattering. In fact, the refined $(\mathrm{Zn}+\mathrm{Cu}): \mathrm{Al}$ ratios of $M 1-M 5 \quad[0.70(5): 0.30(5)$, $0.76(3): 0.24(3), 0.73(4): 0.27(4), 0.74(4): 0.26(4)$ and 0.69(4):0.31(4); Table 4] indicate roughly the same amount of $\mathrm{Al}$ at each site. The observed superlattice reflections arise from the rather small differences in occupancy between these sites, distribution of the oxygens in the $\left[\mathrm{Sb}(\mathrm{OH})_{6}\right]$ octahedron between split sites, and very slight relaxations of all atom positions away from those of the $1 T$ average structure. It is tempting to speculate that there is much more short-range order in the structure, minimizing the strain associated with putting $\mathrm{Al}$ in smaller octahedra, $\mathrm{Cu}$ in distorted octahedra, and $\mathrm{Zn}$ in larger but 


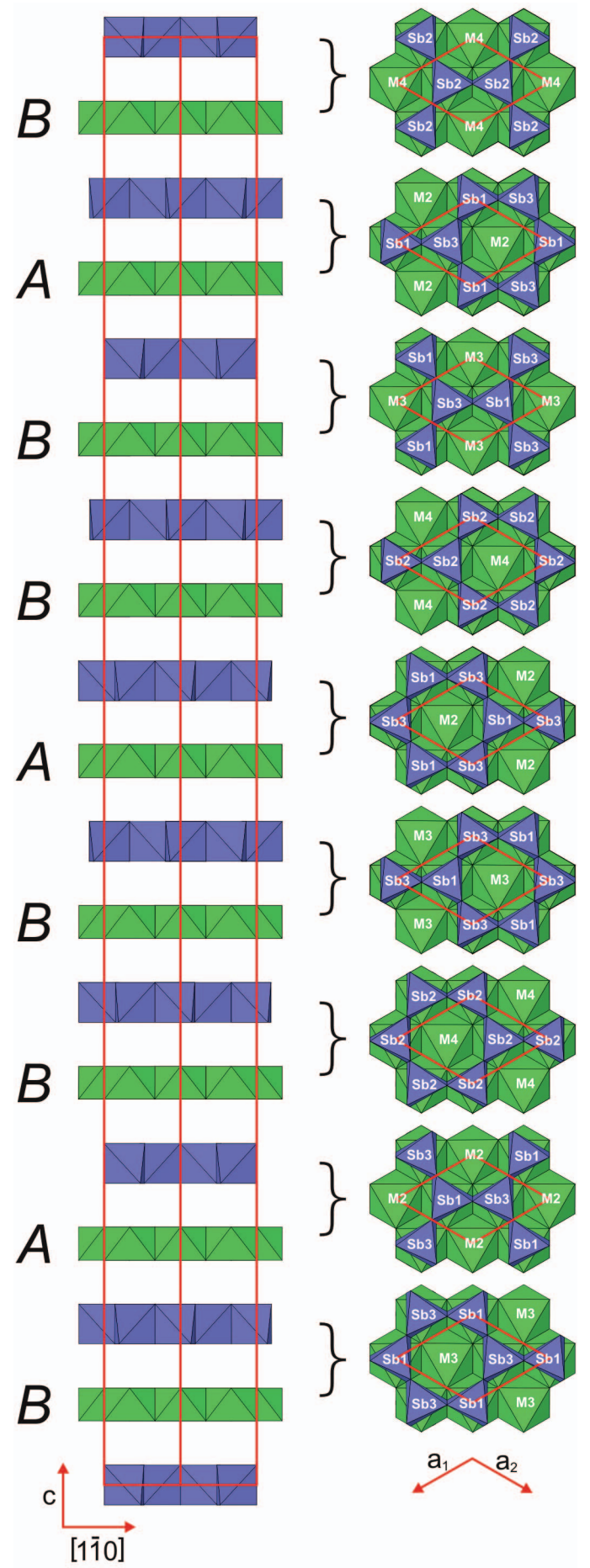

FIG. 3. The crystal structure of zincalstibite-9R; $M$ octahedra are green and $\mathrm{Sb}$ octahedra are purple. Unit-cell outline is in red. undistorted octahedra. However, if such ordering occurs, stacking disorder and domain boundaries are sufficiently common that it is averaged out almost completely on the scale of the $9 R$ cell, which is identifiable only due to weak residual deviations from the $1 T$ structure.

Despite the subtlety of the effects that give rise to the $9 R$ superstructure, it is unequivocally present. The $\sim 88 \AA c$-axis repeat is the longest reported in a $\mathrm{LDH}$ compound to date. It is very likely that similar long-period structures are present in other LDH minerals, but crystals of suitable quality and detectors that can capture weak low-angle diffraction peaks will be required if they are to be found.

\section{Acknowledgements}

An anonymous reviewer provided helpful comments on the manuscript and is thanked. Part of this study was funded by the John Jago Trelawney Endowment to the Mineral Sciences Department of the Natural History Museum of Los Angeles County. The microprobe analyses were supported by a grant to the California Institute of Technology from the Northern California Mineralogical Association. Sylvano Iob is thanked for providing the specimen for study.

\section{References}

Bonaccorsi, E., Merlino, S. and Orlandi, P. (2007) Zincalstibite, a new mineral, and cualstibite: crystal chemical and structural relationships. American Mineralogist, 92, 198-203.

Brese, N.E. and O'Keeffe, M. (1991) Bond-valence parameters for solids. Acta Crystallographica, B47, $192-197$.

Ciriotti, M.E., Möckel, S., Blass, G. and Bortolozzi, G. (2006) Cualstibite: ritrovamenti italiani. Micro, $1 / 2006,19-24$.

Favreau, G., Berbain, C. and Meisser, N. (2003) Cyanophyllite et autres espèces rares de la mine du Tistoulet, Padern (Aude). Le Cahier des Micromonteurs, 4/2003, 17-23.

Mills, S.J., Christy, A.G., Chen, E.C.-C. and Raudsepp, M. (2009) Revised values of the bond valence

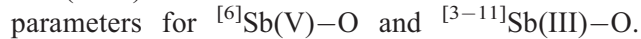
Zeitschrift für Kristallographie, 224, 423-431.

Mills, S.J., Kampf, A.R., Housley, R.M., Favreau, G., Pasero, M., Biagioni, C., Merlino, S., Berbain, C. and Orlandi, P. (2012a) Omsite, $(\mathrm{Ni}, \mathrm{Cu})_{2} \mathrm{Fe}^{3+}(\mathrm{OH})_{6}\left[\mathrm{Sb}(\mathrm{OH})_{6}\right]$, a new member of the cualstibite group from Oms, France. Mineralogical 
Magazine, 76, 1347-1354.

Mills, S.J., Christy, A.G., Génin, J.-M.R., Kameda, T. and Colombo, F. (2012b) Nomenclature of the hydrotalcite supergroup: natural layered double hydroxides. Mineralogical Magazine, 76, 1289-1336.

Patterson, A. L. (1934) A Fourier series method for the determination of the components of interatomic distances in crystals. Physical Review, 46, 372-376.
Sheldrick, G.M. (2008) A short history of SHELX. Acta Crystallographica, A64, 112-122.

Walenta, K. (1984) Cualstibit, ein neues Sekundärmineral aus der Grube Clara im mittleren Schwarzwald (BRD). Chemie der Erde, 43, 255-260.

Wendel, W. and Bayerl, R. (2001) Typlokalität Grube Clara - Erstfunde aus vier Jahrzehnten. Lapis, 26(7/8), 56-60. 